\title{
Utilization of by-product of alumina extraction from fly ash as silicate fertilizer
}

\author{
Yang Luo and Yinghong $\mathrm{Wu}$
}

\begin{abstract}
Calcium silicate hydrate is proposed as a potential silicate fertilizer. It is the main phase of the by-product of a mild hydrochemical process used to extract alumina from coal fly ash. Its preparation by decomposing sodium calcium silicate hydrate, the residue after extracting alumina from coal fly ash, was investigated. The results revealed that the intermediate of the sodium calcium silicate hydrate was easily decomposed into calcium silicate hydrate in a dilute alkaline solution and an available silica content of $28.57 \%$ was obtained under the decomposition conditions of a $30 \mathrm{~g} / \mathrm{L} \quad \mathrm{Na}_{2} \mathrm{O}$ solution, a liquid-volume to solid-mass ratio of 25 , a reaction temperature of $150{ }^{\circ} \mathrm{C}$ and a reaction time of $4 \mathrm{~h}$, with a stirring speed of 600 rpm. Subsequently, Si uptake experiments were conducted on wheat seedlings by hydroponics to test Si's effects on their growth. The results proved that the $\mathrm{Si}$ concentration in the wheat seedling shoots was greatly enhanced from $1.213 \mathrm{mg} / \mathrm{g}$ to $3.983 \mathrm{mg} / \mathrm{g}$ when $0.02 \mathrm{~g}$ of calcium silicate hydrate was distributed in the pot in which $3.87 \mathrm{~g}$ of seeds were cultivated.
\end{abstract}

Index Terms-Calcium silicate hydrate, Available silica, Coal fly ash, Wheat, Si uptake

\section{INTRODUCTION}

Silicon is the second most abundant element in the earth's crust [1]. It can be found in marine as well as terrestrial ecosystems and is essential to the growth of plants. When compared to other elements, however, $\mathrm{Si}$ has received relatively little attention in the field of soil science [1-2]. Regardless, the significance of Si in the growth of crops such as rice and sugarcane has been gradually demonstrated in the last several years [3-4], and its benefits have been reported in several countries including Australia, Brazil, India, and Japan [5]. Si is beneficial to crop yield because it can enhance photosynthesis and improve the crops' resistance to biotic and abiotic stress [6]. Si prevents and eliminates some plant growth disorders: for example, the epidermis cells in crops become silicified after silicon application and the silicified cells would gain increasing resistance against insects and disease with thicker cell walls and cuticles, which would lead to stronger leaves and stems and enhanced ability to carry out photosynthesis. Soluble $\mathrm{Si}$ in soil solutions can be used for $\mathrm{Si}$ uptake in rice [7-9] and wheat [10], but depending on the soil type, its concentration is limited to the range between 0.1 and $2 \mathrm{mmol} \cdot \mathrm{L}^{-1}[11]$.Owing to Si's effect on disease suppression, it is now classified as a plant macronutrient together with $\mathrm{C}$,

This research was supported by grant [T21-711/16-R] from the Research Grants Council (RGC) of the Government of Hong Kong SAR.

Yang Luo is with the Department of Civil Engineering, The University of Hong Kong (e-mail: yangluo@hku.hk).

Yinghong $\mathrm{Wu}$ is with the Department of Mechanical Engineering, The University of Hong Kong (e-mail: yinghong@ @ku.hk).
$\mathrm{H}, \mathrm{O}, \mathrm{N}, \mathrm{P}, \mathrm{S}, \mathrm{K}, \mathrm{Mg}$, and $\mathrm{Ca}$ in the field of plant physiology.

In order to effectively use $\mathrm{Si}$ as a fertilizer, it is essential to have adequate knowledge of the physical and chemical characteristics of $\mathrm{Si}$ sources, and to know the amount of $\mathrm{Si}$ contained within them that is available for plant uptake [4]. For example, many Si-containing industrial by-products have been used as Si fertilizers, but there are large variations in the composition of the materials and the availability of Si [5-6]. So far, a number of extractants have been used to evaluate the amount of potentially available $\mathrm{Si}$ [12], including mineral and organic acids, salt solutions, and water in association with a cation-exchange resin. However, some methods tend to overor under-estimate the amount of $\mathrm{Si}$ that is available to the plants. Japan is the leading country in the study of $\mathrm{Si}$ fertilizers, where the evaluation of available $\mathrm{Si}$ in slags has been conducted using hydrochloric acid $(\mathrm{HCl}, 0.5 \mathrm{~mol} / \mathrm{L})$ [13]. The technique is also the current recognized method according to the Agricultural Industry Standard "NY/T 797-2004 Silicate fertilizer" in China, which indicates that qualified silicate fertilizers must have available silica content of $>20 \%$.

Wheat is a $\mathrm{Si}$ accumulator [14] because it takes up more $\mathrm{Si}$ than that by non-Si-accumulating plants. By choosing a $\mathrm{Si}$ accumulator, it is easier to test the effect of $\mathrm{Si}$ on plant growth. Higher plants take up Si in the form of monomeric silicic acid and accumulate it primarily as amorphous silica. The uptake mechanisms vary among plant species and are either passive (by mass flow of water) or active, allowing a distinction between $\mathrm{Si}$ accumulators ( $\mathrm{Si}$ uptake > water uptake) and $\mathrm{Si}$ non-accumulators ( $\mathrm{Si}$ uptake is similar to or less than water uptake) in addition to Si excluders.

Wollastonite is generally used as a standard $\mathrm{Si}$ source since this material has been used in many studies on Si fertilizers and is rich in calcium silicate $\left(\mathrm{CaSiO}_{3}\right)$ [15]. Calcium silicate can be prepared by various methods via the reactions of different $\mathrm{Si}$ and $\mathrm{Ca}$ sources. Another new method is currently being investigated, namely, the decomposition of an intermediate, $\mathrm{NaCaHSiO}_{4}$, which is produced in a hydrochemical process to extract alumina from coal fly ash. This insoluble alumina-free compound can be broken down easily in a dilute alkali solution [16] and transformed into calcium silicate hydrate. Whether it can be a good silicate fertilizer has yet to be reported, however. If the available silica content in the above calcium silicate hydrate exceeds $20 \%$, it will have great promise in becoming a qualified silicate fertilizer.

Coal fly ash is a powdery residue generated mainly by coal-fired power plants. Since coal is still the major source of energy in China, the output of coal fly ash has increased continuously over the past several years, reaching 540 million 
tons in 2014 [17]. There are huge quantities of coal fly ash stored in ash dams, making it the largest single source of solid waste in China and posing serious environmental and social problems [18]. It has potential for agricultural applications because of it is a rich source of plant macronutrients, including $\mathrm{Si}, \mathrm{Ca}, \mathrm{P}, \mathrm{K}, \mathrm{Mg}, \mathrm{S}, \mathrm{O}$, and micronutrients like $\mathrm{Fe}$, $\mathrm{Mn}, \mathrm{Ni}, \mathrm{Na}$, and $\mathrm{Cl}$. In particular, the mass content of $\mathrm{Si}$ in fly ash is found to be over $30 \%$, but its disease-suppression function is limited owing to its low chemical activity. As a result, coal fly ash consumption in agriculture has been limited and confined to low-quantity additives to farmyard manure.

The study reported in this paper aimed at understanding the variations in available silica content in calcium silicate hydrate as a result of different decomposing conditions of the intermediate $\mathrm{NaCaHSiO}_{4}$ generated during alumina extraction from coal fly ash, thus pinpointing the optimal decomposition conditions. The Si uptake and its effect on plants were then investigated by hydroponics on wheat, a Si-accumulating plant. The findings are expected to have a significant impact on realizing comprehensive utilization of coal fly ash.

\section{EXPERIMENT}

\subsection{Materials}

Aluminum-extraction residues of coal fly ash were obtained from an alumina plant in Henan Province, China. They were first dried in an oven at $105^{\circ} \mathrm{C}$ for $24 \mathrm{~h}$. Wheat seeds and plant pots were purchased from Muxuan Garden in the JingDong Mall in China. The size of the pots was $4.5 \mathrm{~cm} \times 4.5$ $\mathrm{cm} \times 8 \mathrm{~cm}$.

All the other chemicals used for our study, including sodium hydroxide, aluminum hydroxide, calcium hydroxide, potassium chloride, nitric acid, hydrogen peroxide, $95 \%$ ethanol, hydrochloric acid, potassium fluoride, bromothymol blue, and phenol red were of analytical grade and manufactured by China Xilong Chemical Co., Ltd., China. High-purity Milli-Q (Type 1 ultrapure) water, with a resistivity of $<18.2 \mathrm{M} \Omega \cdot \mathrm{cm}$ at ambient temperature, was used for all experiments.

A 1000-mL GSHA-1 stainless steel autoclave (Xintai Co., Ltd., China) was used to conduct the decomposition reactions of aluminum-extraction residues of coal fly ash. To protect the autoclave from corrosion by the alkaline solution, it was lined with pure nickel. A constant-temperature water-bath oscillator (HZ-9212S, Taicang Science \& Technology Equipment Inc., China) was used to extract silica from calcium silicate hydrate. A polyethylene beaker, polyethylene funnel, and polyethylene muddler were used to estimate the content of available silica.

\subsection{Experimental procedures}

The preparation of calcium silicate hydrate proceeded as follows:

(1) The dried aluminum-extraction residues of coal fly ash were placed in a dilute alkali solution in the $1000-\mathrm{mL}$ stainless steel autoclave; the residues and the solution were mixed thoroughly.

(2) The slurry was heated to the desired reaction temperature and kept at that temperature for a certain period of time with constant stirring for the reaction to take place.
(3) The slurry was cooled to $90{ }^{\circ} \mathrm{C}$ using cold water after the reaction was completed.

(4) The final residues were leached and then washed three times with deionized water at $80^{\circ} \mathrm{C}$.

(5) The washed products were dried in an oven at $105^{\circ} \mathrm{C}$ for $12 \mathrm{~h}$.

(6) The dried samples were ground into powder for characterization.

Factors affecting the amount of available silica in the calcium silicate hydrate generated after aluminum-extraction residue decomposition include the reaction temperature, reaction time and stirring speed. To assess these factors, experiments were conducted under various conditions and the content of available silica of the final residues was determined with volumetric analysis using potassium fluorosilicate.

\subsection{Sample analysis}

An inductively coupled plasma optical emission spectrometer (ICP-OES; PE Optima 5300DV, PerkinElmer, USA) and an inductively coupled plasma mass spectrometer (ICP-MS; icAP Qc, Thermo Scientific, USA) were used to analyze the liquid and solid chemical composition of the samples. The phase of the equilibrium solid was identified by X-ray diffraction (XRD; PW226/30, Philips, The Netherlands) with $\mathrm{Cu} \mathrm{K \alpha}$ radiation at $40 \mathrm{kV}$ and $100 \mathrm{~mA}$. Semi-quantitative analysis of solid samples was carried out by X-ray fluorescence. Morphological and mineralogical analyses were conducted using a scanning electron microscope (SEM; 5800SV, JEOL, Japan). The particle-size distribution was analyzed using a particle-size analyzer (Mastersizer 2000, Malvern, UK). The available silica content in calcium silicate was determined with potassium-fluorosilicate volumetric analysis according to "NY/T 797-2004 Silicate fertilizer." 2.4. Experiments on plant growth

To evaluate the Si uptake and its effect on plant growth, wheat was chosen for the experiments because it is a

Si-accumulating plant. Hydroponics [10] was chosen as the cultivation method, because by using water, wheat seeds can be easily cultivated to the seedling stage within several days. The wheat seeds were cultivated in a Si pool and water. Calcium silicate hydrate with the highest available silica content generated under optimal decomposition conditions were selected as the Si pool; water treatment was included for blank control. The selected seeds were soaked in water for $1 \mathrm{~h}$ before cultivation and both $0.01 \mathrm{~g}$ and $0.02 \mathrm{~g}$ calcium silicate hydrate were distributed in the nursery pots with $3.87 \mathrm{~g}$ of seeds. The seeds were cultivated for 7 days with water spraying every few hours until the seedling shoots and roots were ready to be cut and analyzed. Three samples were used for each treatment.

\subsection{Plant analysis}

After germination for 7 days, the seedling shoots and roots were separated from each other and dried for $24 \mathrm{~h}$ at $80{ }^{\circ} \mathrm{C}$ The dried samples were dissolved by acid and their silica content was measured by ICP-OES [10].

\section{RESULTS AND DISCUSSION}

\subsection{Characterization of raw materials}

The results of chemical analysis of the aluminum-extraction residue of coal fly ash are shown in Table $1 . \mathrm{SiO}_{2}$ and $\mathrm{CaO}$ were the principle components. The mineral phases of the aluminum-extraction residues of coal fly ash were also examined, as shown in Fig. 1. The identified 
crystalline phases included $\mathrm{NaCaHSiO}_{4}, \mathrm{Ca}(\mathrm{OH})_{2}$, and $\mathrm{Na}_{8} \mathrm{Al}_{6} \mathrm{Si}_{6} \mathrm{O}_{24}(\mathrm{OH})_{2}\left(\mathrm{H}_{2} \mathrm{O}\right)_{2}$. SEM images of the residues are shown in Fig. 2, revealing virgate and irregular shapes of the mineral phases.

Table 1 Chemical composition of aluminum-extraction residue of coal fly ash.

\begin{tabular}{|c|c|c|c|c|c|c|c|c|}
\hline & $\omega\left(\mathrm{SiO}_{2}\right)$ & $\omega(\mathrm{CaO})$ & $\omega\left(\mathrm{Al}_{2} \mathrm{O}_{3}\right)$ & $\omega\left(\mathrm{Na}_{2} \mathrm{O}\right)$ & $\omega\left(\mathrm{TiO}_{2}\right)$ & $\omega(\mathrm{MgO})$ & \multirow[b]{2}{*}{$\mathrm{Al}_{2} \mathrm{O}_{3} / \mathrm{SiO}_{2}$} & \multirow[b]{2}{*}{$\mathrm{CaO} / \mathrm{SiO}_{2}$} \\
\hline & $1 \%$ & $/ \%$ & $1 \%$ & $1 \%$ & $/ \%$ & $/ \%$ & & \\
\hline Residue & 29.93 & 37.80 & 2.17 & 14.72 & 1.92 & 0.96 & 0.07 & 1.26 \\
\hline
\end{tabular}

$\mathrm{Al}_{2} \mathrm{O}_{3} / \mathrm{SiO}_{2}$ : Mass ratio of alumina to silica

$\mathrm{CaO} / \mathrm{SiO}_{2}$ : Mass ratio of calcium oxide to silica

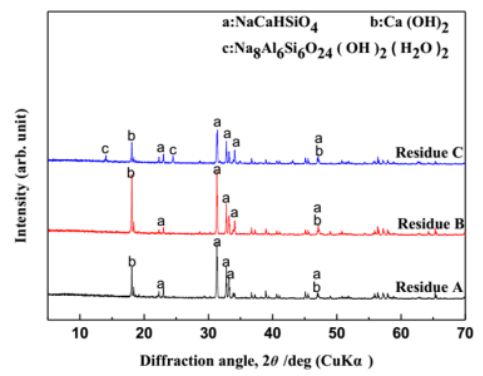

Fig. 1. XRD patterns of aluminum-extraction residue samples of coal fly ash.

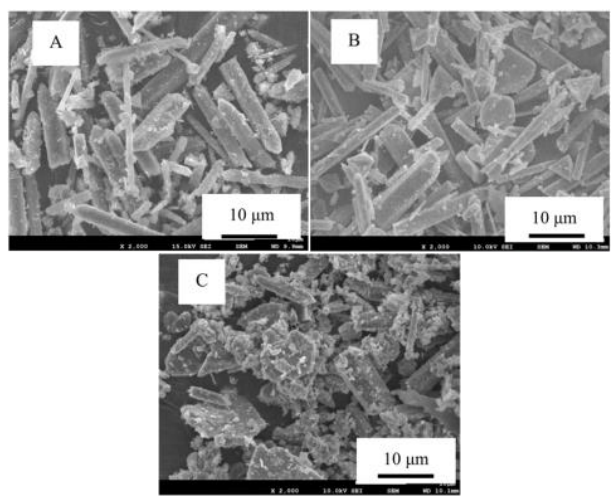

Fig. 2. SEM images of aluminum-extraction residue samples of coal fly ash.

\subsubsection{Mechanism of generation of calcium silicate hydrate}

Coal fly ash, a lower-grade aluminum-containing resource had its alumina component extracted by a hydrochemical process. Depending on the reaction conditions, $\mathrm{Al}_{2} \mathrm{O}_{3}$ in coal fly ash may be converted into sodalite-grossularite and soluble sodium aluminate, while $\mathrm{SiO}_{2}$ can be converted into sodalite-grossularite and insoluble $\mathrm{NaCaHSiO}_{4}$. The desired phase, $\mathrm{NaCaHSiO}_{4}$, was created through the reaction described by Eq. (1) under optimal conditions. Under some conditions such as low values of alkaline concentration, liquid-volume/solid-mass ratio $(\mathrm{L} / \mathrm{S})$, reaction temperature, $\mathrm{CaO} / \mathrm{SiO}_{2}$ mass ratio, and residence time, however, undesired phases consisting predominantly of sodalite and grossularite can emerge via the reactions described by Eqs. (2) and (3).

$\mathrm{SiO}_{2}+\mathrm{NaOH}+\mathrm{Ca}(\mathrm{OH})_{2} \rightarrow \mathrm{H}_{2} \mathrm{O}+\mathrm{NaCaHSiO}_{4}$

$8 \mathrm{NaOH}+6 \mathrm{SiO}_{2}+3 \mathrm{Al}_{2} \mathrm{O}_{3}+\mathrm{H}_{2} \mathrm{O} \rightarrow \mathrm{Na}_{8} \mathrm{Al}_{6} \mathrm{Si}_{6} \mathrm{O}_{24}(\mathrm{OH})_{2}\left(\mathrm{H}_{2} \mathrm{O}\right)_{2}$

$6 \mathrm{SiO}_{2}+3 \mathrm{Al}_{2} \mathrm{O}_{3}+\mathrm{Ca}(\mathrm{OH})_{2} \rightarrow 3 \mathrm{H}_{2} \mathrm{O}+\mathrm{Ca}_{3} \mathrm{Al}_{2}\left(\mathrm{SiO}_{4}\right)_{3}$

$\mathrm{NaCaHSiO}_{4}$ can be easily broken down in a dilute alkali solution like $\mathrm{NaOH}$ via the reactions shown in Eqs. (4) and (5). Equation (6) shows that the final phase of the residue transformed into $\mathrm{Ca}_{5}(\mathrm{OH})_{2} \mathrm{Si}_{6} \mathrm{O}_{16} \cdot 4 \mathrm{H}_{2} \mathrm{O}$ (tobermorite), a type of calcium silicate hydrate when $\mathrm{CaO} / \mathrm{SiO}_{2}$ was around 1.0. But when $\mathrm{CaO} / \mathrm{SiO}_{2}$ was above 1.2 , the final phase was changed to another type of calcium silicate hydrate, as shown by Eq. (7).

$\mathrm{NaCaHSiO}_{4}+\mathrm{NaOH}=\mathrm{Na}_{2} \mathrm{SiO}_{3}+\mathrm{Ca}(\mathrm{OH})_{2}$

$\mathrm{yNa} \mathrm{SiO}_{3}+\mathrm{yCa}(\mathrm{OH})_{2}+\mathrm{xH}_{2} \mathrm{O}=\mathrm{yCaO} \cdot \mathrm{SiO}_{2} \cdot \mathrm{xH}_{2} \mathrm{O}+2 \mathrm{yNaOH}$

$5 \mathrm{CaO} \cdot \mathrm{SiO}_{2} \cdot \mathrm{H}_{2} \mathrm{O}+\mathrm{SiO}_{2}+3 \mathrm{H} 2 \mathrm{O}=\mathrm{Ca} 5(\mathrm{OH})_{2} \mathrm{Si}_{6} \mathrm{O}_{16} \cdot 4 \mathrm{H}_{2} \mathrm{O}$

$\mathrm{yCaO}+\mathrm{CaO} \cdot \mathrm{SiO}_{2} \cdot \mathrm{xH}_{2} \mathrm{O}=(\mathrm{y}+1) \mathrm{CaO} \cdot \mathrm{SiO}_{2} \cdot \mathrm{xH}_{2} \mathrm{O}$

(4)

3.2.2. Effect of reaction temperature

To study the effect of reaction temperature, experiments were performed using a $\mathrm{Na}_{2} \mathrm{O}$ concentration of $30 \mathrm{~g} / \mathrm{L}, \mathrm{L} / \mathrm{S}$ of $25 \mathrm{~mL} / \mathrm{g}$, reaction time of $4 \mathrm{~h}$, and stirring speed of $600 \mathrm{rpm}$ with aluminum-extraction residue. The measurements were obtained within the reaction temperature range of 130-230 ${ }^{\circ} \mathrm{C}$. The results are shown in Table 2 and Figs. 3, 4 and 5.

China's agricultural industry standard "NY/T 797-2004 Silicate fertilizer" states that the content of available silica of a qualified silicate fertilizer should be higher than $20 \%$. As seen in Table 2 , the concentration of available silica in the calcium silicate hydrate generated at $150{ }^{\circ} \mathrm{C}$ reached $28.57 \%$, which means that $93.5 \%$ of its total $\mathrm{SiO}_{2}$ content was activated through the mild hydrochemical process. The $\mathrm{Na}_{2} \mathrm{O}$ content of $1.46 \%$ demonstrates that complete decomposition of $\mathrm{NaCaHSiO}_{4}$ and full recovery of sodium oxide occurred. The other macronutrient $\mathrm{Ca}$ in the calcium silicate hydrate was also abundant because $\mathrm{CaO}$ made up for $37.17 \%$ of the calcium silicate hydrate.

Table 2 Concentration of available silica and other components of calcium silicate hydrates generated at different temperature.

\begin{tabular}{ccccccc}
\hline Reaction temperature $/{ }^{\circ} \mathrm{C}$ & 130 & 140 & 150 & 160 & 200 & 230 \\
\hline$\omega\left(\right.$ Available $\left.\mathrm{SiO}_{2}\right) / \%$ & 26.65 & 27.64 & 28.57 & 28.3 & 19.91 & 20.36 \\
\hline$\omega\left(\right.$ total $\mathrm{SiO}_{2}$ content $) / \%$ & 31.1 & 32.47 & 30.55 & 32.82 & 30.13 & 33.57 \\
\hline $\begin{array}{c}\text { Percentage availability of } \mathrm{SiO}_{2} \\
\text { for plant uptake } / \%\end{array}$ & 85.7 & 85.1 & 93.5 & 86.2 & 66.1 & 60.6 \\
\hline$\omega\left(\mathrm{Na}_{2} \mathrm{O}\right) / \%$ & 2.83 & 2.12 & 1.46 & 1.72 & 6.12 & 1.55 \\
\hline$\omega(\mathrm{CaO}) / \%$ & 38.09 & 39.03 & 37.17 & 38.96 & 37.4 & 41.03 \\
\hline
\end{tabular}

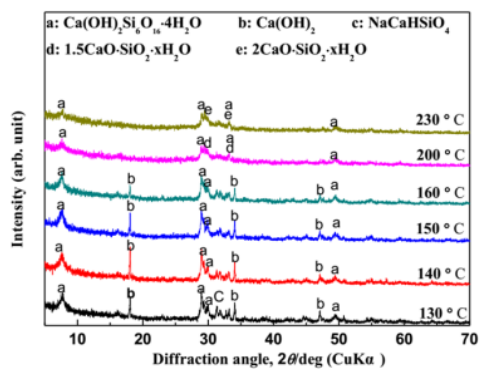

Fig. 3. XRD patterns of calcium silicate hydrates generated by reactions at different temperatures.

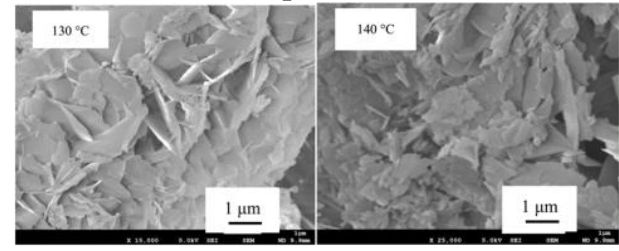




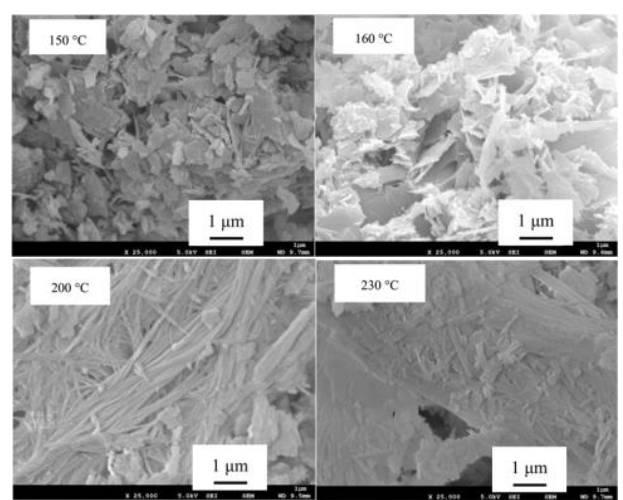

Fig. 4. SEM images of calcium silicate hydrates generated by reactions at different temperatures.

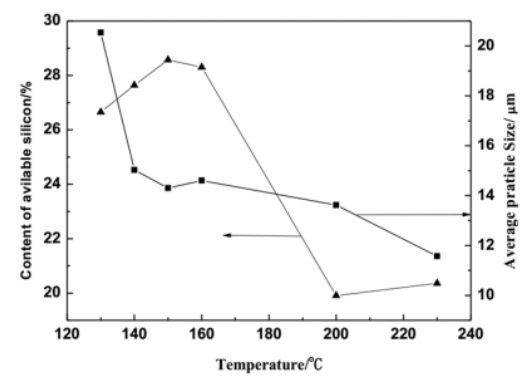

Fig. 5. Effect of temperature on the concentration of available silica and average particle size of calcium silicate hydrates.

Figure 3 shows XRD patterns of calcium silicate hydrates that were generated at different temperatures. At $130{ }^{\circ} \mathrm{C}$, the crystal phases were mainly $\mathrm{Ca}_{5}(\mathrm{OH})_{2} \mathrm{Si}_{6} \mathrm{O}_{16} \cdot 4 \mathrm{H}_{2} \mathrm{O}$ and $\mathrm{Ca}(\mathrm{OH})_{2}$, as well as a small amount of $\mathrm{NaCaHSiO}_{4}$. The existence of $\mathrm{Ca}(\mathrm{OH})_{2}$ was due to its excessive addition during aluminum extraction of the coal fly ash. As the temperature continued to increase, the $\mathrm{Ca}_{5}(\mathrm{OH})_{2} \mathrm{Si}_{6} \mathrm{O}_{16} \cdot 4 \mathrm{H}_{2} \mathrm{O}$ peaks first strengthened and then weakened. When the temperature reached $200{ }^{\circ} \mathrm{C}$, the peaks of $\mathrm{Ca}_{5}(\mathrm{OH})_{2} \mathrm{Si}_{6} \mathrm{O}_{16} \cdot 4 \mathrm{H}_{2} \mathrm{O}$ were very small, the peaks of $\mathrm{Ca}(\mathrm{OH})_{2}$ disappeared, and peaks corresponding to $1.5 \mathrm{CaO} \cdot \mathrm{SiO}_{2} \cdot \mathrm{xH}_{2} \mathrm{O}$ emerged, which then converted to $2 \mathrm{CaO} \cdot \mathrm{SiO}_{2} \cdot \mathrm{xH}_{2} \mathrm{O}$ when the temperature reached $230{ }^{\circ} \mathrm{C}$, along with a sharp decrease in the amount of available silica according to Table 2 . These results further prove that the high content of available $\mathrm{SiO}_{2}$ in the calcium silicate hydrate was related to the presence of $\mathrm{Ca}_{5}(\mathrm{OH})_{2} \mathrm{Si}_{6} \mathrm{O}_{16} \cdot 4 \mathrm{H}_{2} \mathrm{O}$.

Figure 4 shows that the calcium silicate hydrates generated between 130 and $160{ }^{\circ} \mathrm{C}$ were amorphous, but they were in the fibrous phases when generated at 200 and $230{ }^{\circ} \mathrm{C}$. Because amorphous Si can be more easily absorbed by plants, it is easy to understand that a larger quantity of available silica was measured in calcium silicate hydrate in the amorphous state.

Figure 5 demonstrates that a smaller particle size contributed to the higher content of available silica. As shown in the figure, a higher reaction temperature contributed to a fine particle dispersion in a mild hydrochemical process, but the amount of available silica did not continue to rise after 160 ${ }^{\circ} \mathrm{C}$ because the phase changes from $\mathrm{Ca}_{5}(\mathrm{OH})_{2} \mathrm{Si}_{6} \mathrm{O}_{16} \cdot 4 \mathrm{H}_{2} \mathrm{O}$ to $1.5 \mathrm{CaO} \cdot \mathrm{SiO}_{2} \cdot \mathrm{xH}_{2} \mathrm{O}$ and $2 \mathrm{CaO} \cdot \mathrm{SiO}_{2} \cdot \mathrm{xH}_{2} \mathrm{O}$ began to take place, which caused the amorphous phase to disappear.

It can be concluded from the above results that $150{ }^{\circ} \mathrm{C}$ was the optimal reaction temperature when the reaction time was 4 $\mathrm{h}$, stirring speed was $600 \mathrm{rpm}, \mathrm{Na}_{2} \mathrm{O}$ concentration was 30 $\mathrm{g} / \mathrm{L}$, and $\mathrm{L} / \mathrm{S}$ was $25 \mathrm{~mL} / \mathrm{g}$.

\subsubsection{Effect of reaction time}

To study the effect of reaction time, two sets of experiments were performed using a $\mathrm{Na}_{2} \mathrm{O}$ concentration of $30 \mathrm{~g} / \mathrm{L}, \mathrm{L} / \mathrm{S}$ of $25 \mathrm{~mL} / \mathrm{g}$. The first set of experiments was performed at a reaction temperature of $130{ }^{\circ} \mathrm{C}$ and stirring speed of $600 \mathrm{rpm}$. The second set of experiments was performed at a reaction temperature of $150{ }^{\circ} \mathrm{C}$ and stirring speed of $600 \mathrm{rpm}$. The results are shown in Tables 3 and 4 and Figs. 6 and 7.

Table 3 Concentration of available silica and other components of calcium silicate hydrates generated by reactions over different periods of time.

\begin{tabular}{c|c|c|c|c|c}
\hline Reaction temperature $/{ }^{\circ} \mathrm{C}$ & \multicolumn{2}{|c|}{130} & \multicolumn{3}{c}{150} \\
\hline Reaction time $/ \mathrm{h}$ & 2 & 4 & 4 & 6 & 8 \\
\hline$\omega\left(\right.$ Available $\left.\mathrm{SiO}_{2}\right) / \%$ & 21.48 & 26.65 & 28.57 & 26.96 & 27.85 \\
\hline$\omega\left(\right.$ total $\mathrm{SiO}_{2}$ content $) / \%$ & 32.1 & 31.1 & 30.55 & 33.09 & 33.24 \\
\hline Percentage availability of $\mathrm{SiO}_{2}$ for plant uptake $/ \%$ & 66.92 & 85.69 & 93.5 & 81.47 & 83.78 \\
\hline$\omega\left(\mathrm{Na}_{2} \mathrm{O}\right) / \%$ & 2.9 & 2.83 & 1.46 & 1.43 & 1.06 \\
\hline$\omega(\mathrm{CaO}) / \%$ & 37.8 & 38.09 & 37.17 & 40.23 & 39.79 \\
\hline
\end{tabular}

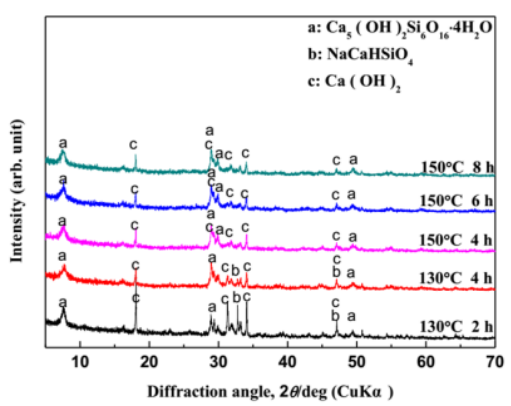

Fig. 6. XRD patterns of calcium silicate hydrates generated by reactions of different durations.

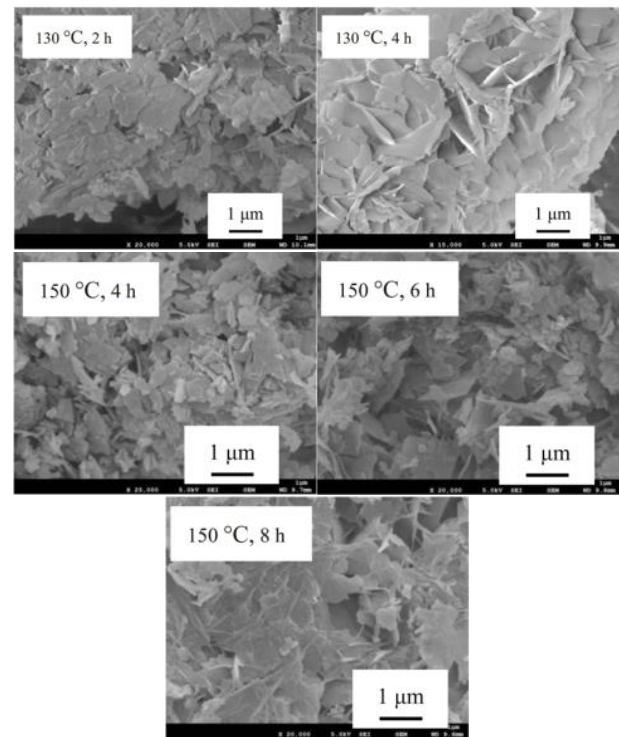

Fig. 7. SEM images of calcium silicate hydrates generated by reactions of different durations.

Table 4 Effect of reaction time on content of available silica and average particle size of calcium silicate hydrates. 


\begin{tabular}{c|c|c|c|c|c}
\hline Reaction temperature $/{ }^{\circ} \mathrm{C}$ & \multicolumn{2}{|c|}{130} & \multicolumn{3}{c}{150} \\
\hline Reaction time $/ \mathrm{h}$ & 2 & 4 & 4 & 6 & 8 \\
\hline$\omega\left(\right.$ Available $\left.\mathrm{SiO}_{2}\right) / \%$ & 21.48 & 26.65 & 28.57 & 26.96 & 27.85 \\
\hline Average particle size / $\mu \mathrm{m}$ & 16.1 & 16.153 & 14.3 & 16.59 & 16.402 \\
\hline
\end{tabular}

Figure 6 illustrates that the reactions at $130{ }^{\circ} \mathrm{C}$ were not complete, with some $\mathrm{NaCaHSiO}_{4}$ remaining without transformation into $\mathrm{Ca}_{5}(\mathrm{OH})_{2} \mathrm{Si}_{6} \mathrm{O}_{16} \cdot 4 \mathrm{H}_{2} \mathrm{O}$. A longer reaction time pushed the reaction forward, as shown by the $\mathrm{NaCaHSiO}_{4}$ peaks that weakened and then completely disappeared. At $150{ }^{\circ} \mathrm{C}$, the reaction transformed all $\mathrm{NaCaHSiO}_{4}$ into $\mathrm{Ca}_{5}(\mathrm{OH})_{2} \mathrm{Si}_{6} \mathrm{O}_{16} \cdot 4 \mathrm{H}_{2} \mathrm{O}$.

Table 4 shows that the average particle size of the calcium silicate hydrate was the lowest when the reaction time was $4 \mathrm{~h}$ and the reaction temperature was $150{ }^{\circ} \mathrm{C}$. This temperature contributed to a more thorough reaction and $4 \mathrm{~h}$ of reaction was enough to break the particles. The particles would begin to agglomerate if the reaction time was further extended. Figure 7 shows that the amount of amorphous $\mathrm{Ca}_{5}(\mathrm{OH})_{2} \mathrm{Si}_{6} \mathrm{O}_{16} \cdot 4 \mathrm{H}_{2} \mathrm{O}$ decreased when the reaction time reached $8 \mathrm{~h}$, which also led to the drop in content of available silica.

It can be concluded from the above results that 4 hours of reaction was the optimal duration when the reaction temperature was $150{ }^{\circ} \mathrm{C}$, stirring speed was $600 \mathrm{rpm}, \mathrm{Na}_{2} \mathrm{O}$ concentration was $30 \mathrm{~g} / \mathrm{L}$, and $\mathrm{L} / \mathrm{S}$ was $25 \mathrm{~mL} / \mathrm{g}$.

\subsubsection{Effect of stirring speed}

To study the effect of the stirring speed, experiments were performed using a $\mathrm{Na}_{2} \mathrm{O}$ concentration of $30 \mathrm{~g} / \mathrm{L}, \mathrm{L} / \mathrm{S}$ of 25 $\mathrm{mL} / \mathrm{g}$, reaction temperature of $150{ }^{\circ} \mathrm{C}$, and reaction time of $4 \mathrm{~h}$ with the aluminum-extraction residue. The stirring speed was separately set at $300 \mathrm{rpm}, 600 \mathrm{rpm}$, and $700 \mathrm{rpm}$. The results are shown in Tables 5 and 6 and Figs. 8 and 9.

As shown in Table 5, the calcium silicate hydrates generated by the reactions with different stirring speeds contained different amounts of available silica. According to Figs. 8 and 9, however, the hydrate particles had similar composition and phase microstructure. The results in Table 6 further demonstrate that a high stirring speed provided more power to break the particles, and smaller particle size was one of the main causes of the higher content of available silica. A speed of $600 \mathrm{rpm}$ had slight advantage over that of $700 \mathrm{rpm}$ and should be chosen as the reaction stirring speed when energy consumption is taken into consideration.

Table 5 Concentration of available silica and other components of calcium silicate hydrates generated by reactions at different stirring speeds.

\begin{tabular}{cccc}
\hline Stirring speed $/$ rpm & 300 & 600 & 700 \\
\hline$\omega\left(\right.$ Available $\left.\mathrm{SiO}_{2}\right) / \%$ & 25.56 & 28.57 & 28.52 \\
\hline$\omega\left(\right.$ total $\mathrm{SiO}_{2}$ content $) / \%$ & 31.56 & 30.55 & 32.56 \\
\hline Percentage availability of $\mathrm{SiO}_{2}$ for plant uptake $/ \%$ & 80.99 & 93.5 & 87.59 \\
\hline$\omega\left(\mathrm{Na}_{2} \mathrm{O}\right) / \%$ & 3.63 & 1.46 & 1.92 \\
\hline$\omega(\mathrm{CaO}) / \%$ & 38.86 & 37.17 & 40.05 \\
\hline
\end{tabular}

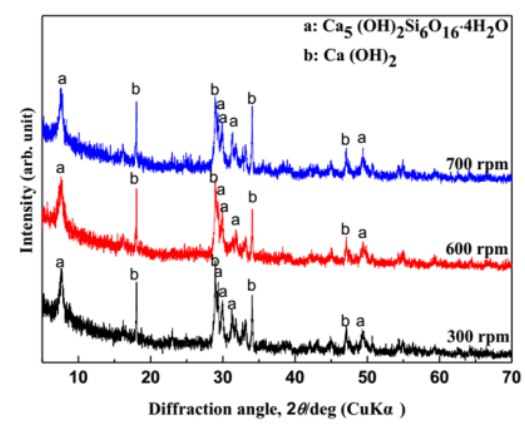

Fig. 8. XRD patterns of calcium silicate hydrates generated by reactions at different stirring speeds.

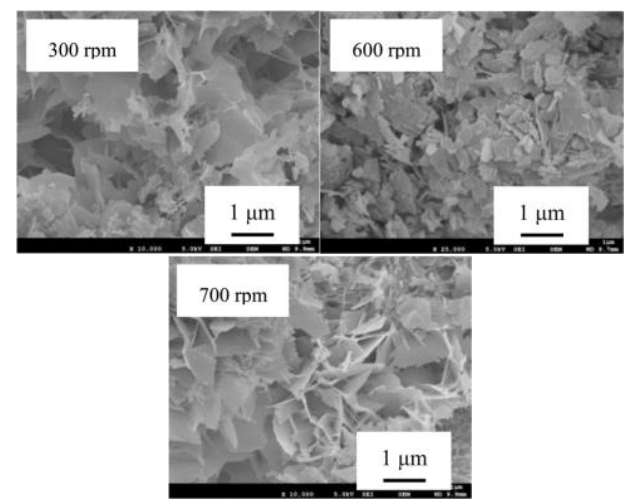

Fig. 9. SEM images of calcium silicate hydrates generated by reactions at different stirring speeds.

Table 6 Effect of stirring speed on content of available silica and average particle size of calcium silicate hydrates.

\begin{tabular}{c|c|c|c}
\hline Stirring speed / rpm & 300 & 600 & 700 \\
\hline$\omega\left(\right.$ Available $\left.\mathrm{SiO}_{2}\right) / \%$ & 25.56 & 28.57 & 28.52 \\
\hline Average particle size $/ \mu \mathrm{m}$ & 21.941 & 14.3 & 16.102 \\
\hline
\end{tabular}

The above results indicate that $600 \mathrm{rpm}$ was the optimal stirring speed when the reaction temperature was $150{ }^{\circ} \mathrm{C}$, reaction time was $4 \mathrm{~h}, \mathrm{Na}_{2} \mathrm{O}$ concentration was $30 \mathrm{~g} / \mathrm{L}$, and $\mathrm{L} / \mathrm{S}$ was $25 \mathrm{~mL} / \mathrm{g}$.

\subsection{Optimal conditions}

From the above experimental results, we determined the optimal conditions for increasing the content of available silica in calcium silicate hydrate. The conditions are summarized as follows: $\mathrm{Na}_{2} \mathrm{O}$ concentration of $30 \mathrm{~g} / \mathrm{L}, \mathrm{L} / \mathrm{S}$ of $25 \mathrm{mg} / \mathrm{L}$, reaction temperature of $150^{\circ} \mathrm{C}$, reaction time of $4 \mathrm{~h}$, and stirring speed of $600 \mathrm{rpm}$. Under these conditions, the content of available silica could reach $28.57 \%$, which is $43 \%$ higher than the standard value listed in China's Agricultural industry standard "NY/T 797-2004 Silicate fertilizer."

\subsection{Characteristics of optimal product}

The XRD pattern of calcium silicate hydrate generated under optimal conditions is shown in Fig. 10. The pattern indicates that the main phase was $\mathrm{Ca}_{5}(\mathrm{OH})_{2} \mathrm{Si}_{6} \mathrm{O}_{16} \cdot 4 \mathrm{H}_{2} \mathrm{O}$. The presence of $\mathrm{Ca}(\mathrm{OH})_{2}$ resulted from its excessive addition during the alumina-extraction process of coal fly ash, and its existence contributed to the higher available silica content. Phase analysis confirmed that the silica activation was accomplished via the mild hydrochemical process by the phase transformation of $\mathrm{SiO}_{2}$ or $3 \mathrm{Al}_{2} \mathrm{O}_{3} \cdot 2 \mathrm{SiO}_{2}$ to $\mathrm{Ca}_{5}(\mathrm{OH})_{2} \mathrm{Si}_{6} \mathrm{O}_{16} \cdot 4 \mathrm{H}_{2} \mathrm{O}$, whose silica component is more 
easily absorbed by plants.

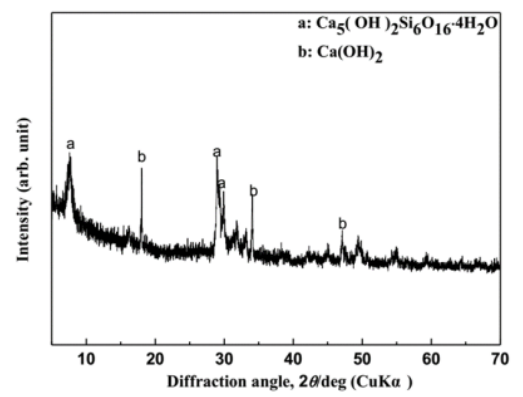

Fig. 10. XRD pattern of the optimal product.

The composition of calcium silicate hydrate generated under optimal conditions is shown in Table 7. Compared with coal fly ash, the content of available silica significantly increased after the mild hydrochemical process, rising from $2.79 \%$ to $28.57 \%$. Meanwhile, the content of $\mathrm{Al}_{2} \mathrm{O}_{3}$ and $\mathrm{CaO}$ varied significantly owing to the alumina-extraction process and formation of $\mathrm{Ca}_{5}(\mathrm{OH})_{2} \mathrm{Si}_{6} \mathrm{O}_{16} \cdot 4 \mathrm{H}_{2} \mathrm{O}$.

Table 7 Concentration of available silica and other components of coal fly ash and calcium silicate hydrate generated under optimal conditions.

\begin{tabular}{ccccccc}
\hline & & $\omega($ Available & $\omega($ activated & $\omega\left(\mathrm{Al}_{2} \mathrm{O}_{3}\right)$ & & $\omega\left(\mathrm{Na}_{2} \mathrm{O}\right)$ \\
Material & $\omega\left(\mathrm{SiO}_{2}\right) \%$ & $\left.\mathrm{SiO}_{2}\right) / \%$ & $\left.\mathrm{SiO}_{2}\right) / \%$ & $/ \%$ & $\omega(\mathrm{CaO}) / \%$ & $/ \%$ \\
\hline Coal fly ash & 39.34 & 2.79 & 7.10 & 52.37 & 1.35 & 0.48 \\
\hline Optimal & & & & & & \\
product & 30.55 & 28.57 & 93.52 & 2.21 & 37.17 & 1.46 \\
\hline
\end{tabular}

\subsection{Si uptake and its effect}

After germination for 7 days, the seedling shoots and roots were separated from each other and dried for $24 \mathrm{~h}$ at $80{ }^{\circ} \mathrm{C}$. The dried samples were dissolved by acid and their silica content was measured by ICP-OES. Figure 11 shows the Si concentration in the shoots and roots as the amount of calcium silicate hydrate that was applied increased.

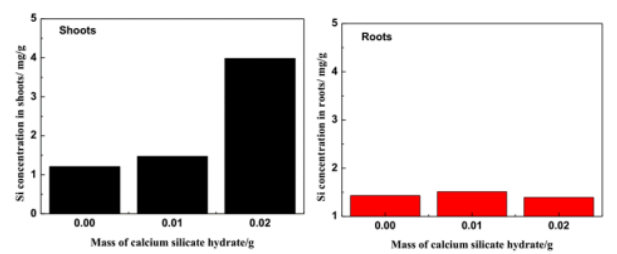

Fig. 11. Si uptake in wheat seedling shoots and roots after different amounts of calcium silicate hydrate were applied.

Figure 11 shows that the $\mathrm{Si}$ concentration in the shoots increased as the concentration of the Si pool was increased, while the Si concentration in the roots remained unchanged. The Si concentration in the shoots was $1.213 \mathrm{mg} / \mathrm{g}$ when the seedling was cultivated in water, $1.473 \mathrm{mg} / \mathrm{g}$ when the seedling was cultivated in water and $0.01 \mathrm{~g}$ of calcium silicate hydrate, and $3.983 \mathrm{mg} / \mathrm{g}$ when the seedling was cultivated in water and $0.02 \mathrm{~g}$ of calcium silicate hydrate. The last value is $228 \%$ higher than that when the seedling was cultivated in water only. These results suggest that $\mathrm{Si}$ accumulation mainly took place in seedling shoots but not roots.
Sillicon's function in preventing and eliminating plant-growth disorder compared to plants grown without $\mathrm{Si}$ addition has been demonstrated in many papers. The epidermis cells in crops become silicified after silicon application, and the silicified cells would gain increasing resistance against insects and disease with thicker cell walls and cuticles, which contribute to stronger leaves and stems and enhance the ability to carry out photosynthesis.

As explained in the previous sections, the mild hydrochemical process is useful for utilizing the by-product of extracting alumina from coal fly ash as a potential silicate fertilizer. This process can solve the environmental problems caused by the deposition of coal fly ash and also offer the opportunity to realize economical profit by maximizing the utilization of coal fly ash.

\section{CONCLUSIONS}

Calcium silicate hydrate, a potential silicate fertilizer, was prepared by decomposing sodium calcium silicate hydrate, the residue of alumina extraction from coal fly ash. The factors affecting the amount of available silica were explored, they were found to include the reaction temperature, reaction time and stirring speed. An available silica content of $28.57 \%$ was obtained under the following conditions: $30 \mathrm{~g} / \mathrm{L}$ of $\mathrm{Na} 2 \mathrm{O}$ solution, a liquid volume to solid mass ratio of 25 , a reaction temperature of $150{ }^{\circ} \mathrm{C}$, a reaction time of $4 \mathrm{~h}$, and a stirring speed of $600 \mathrm{rpm}$. The Si concentration in wheat seedling shoots was greatly enhanced from $1.213 \mathrm{mg} / \mathrm{g}$ to $3.983 \mathrm{mg} / \mathrm{g}$ when $0.02 \mathrm{~g}$ of calcium silicate hydrate was distributed in the plant pot in which $3.87 \mathrm{~g}$ of seeds were cultivated. The mild hydrochemical process was useful for facilitating the utilization of calcium silicate hydrate as a potential silicate fertilizer.

\section{REFERENCES}

[1] M. Sommer, D. Kaczorek, Y. Kuzyakov, J. Breuer, Silicon pools and fluxes in soils and landscapes - a review, J. Plant Nutr. Soil Sci. 169 (2006) 310-329.

[2] J. Cooke, M.R. Leishman, Is plant ecology more siliceous than we realise? Trends Plant Sci. 16 (2011) 61-68.

[3] N.K. Savant, G.H. Snyder, L.E. Datnoff, Silicon management and sustainable rice production, Adv. Agron. 58 (1997) 151-199.

[4] N.K. Savant, G.H. Korndörfer, L.E. Datnoff, G.H. Snyder, Silicon nutrition and sugarcane production: A review, J. Plant Nutr. 22 (1999) 1853 [5] M.G. Keeping, O.L. Reynolds, Silicon in agriculture: new insights, new significance and growing application, Ann. Appl. Biol. 155 (2009) 153-154 [6] J.F. Ma, E.Takahashi, Soil, fertilizer, and plant silicon research in Japan, J. Sci. Soil Manure. 74 (2003) 126

[7] A. Hasebe, K. Limura, Effects of concentration of silicon in culture solution of rice growth, J. Sci. Soil Manure jpn. 57 (1986) 42-48.

[8] K. Kitada, K. Kamekawa, Y. Akiyama, The dissolution of silica in soil in rotational paddy fields by the surface water dissolution method, Jpn. J. Soil Sci. Plant Nutr. 63 (1992) 31-38.

[9] C. Keller, M. Rizwan, J.C. Davidian, O.S. Pokrovsky, N. Bovet, P. Chaurand, J.D. Meunier, Effect of silicon on wheat seedlings (Triticum turgidum L.) grown in hydroponics and exposed to 0 to $30 \mu \mathrm{M} \mathrm{Cu}$, Planta. 241 (2015) 847-860.

[10] M. Gocke, L. Wu, M. Sommer, Y. Kuzyakov, Silicon uptake by wheat: Effects of Si pools and pH, J. Plant Nutr. Soil Sci. 176 (2013) 551-560.

[11] N. Kato, N. Owa, Dissolution of slag fertilizers in a paddy soil and $\mathrm{Si}$ uptake by rice plant, Soil Sci. Plant Nutr. 43 (1997) 329.

[12] S. Tsukuda, Official methods of analysis of fertilizers, second ed., Japan, 1987. 
[13] S.C. Jarvis, The uptake and transport of silicon by perennial ryegrass and wheat, Plant Soil. 97 (1987) 429-438.

[14] G.B. Buck, G.H. Korndörfer, L.E. Datnoff, Extractors for estimating plant available silicon from potential silicon fertilizer sources, J. Plant Nutr. 34 (2010) 272-282.

[15] R. Zhang, S. Ma, Q. Yang, S. Zheng, Y. Zhang, Research on $\mathrm{NaCaHSiO} 4$ decomposition in sodium hydroxide solution, Hydrometallurgy 108 (2011) 205-213

[16] The 12th Five-Year Plan for Utilization of the Industrial Solid Wastes, Ministry of industry and information technology, 2012.
[17] R.B. Finkelman, W. Orem, V. Castranova, C.A. Tatu, H.E. Belkin, B. Zheng, H.E. Lerch, S.V. Maharaj, A.L. Bates, Health impacts of coal and coal use: possible solutions, Int. J. Coal Geol. 50 (2002) 425-443.

[18] F. Huggins, F. Goodarzi, Environmental assessment of elements and polyaromatic hydrocarbons emitted from a Canadian coal-fired power plant, Int. J. Coal Geol. 77 (2009) 282-288.

[19] Q. Yang, S. Ma, S. Zheng, R. Zhang, Recovery of alumina from circulating fluidized bed combustion Al-rich fly ash using mild hydrochemical process, Trans. Nonferrous Met. Soc. China. 24 (2014) 1187-1195. 